\title{
Intraperitoneal Hemorrhage in a Peritoneal Dialysis Patient Using Dabigatran: A Case Report
}

\author{
Dabigatran Kullanan Periton Diyalizi Hastasında Intraperitoneal Hemoraji: \\ Olgu Sunumu
}

\author{
Egemen Cebeci, Nilay Şengül Samancı*, Meltem Gürsu, Abdullah Şumnu, Serhat Karadağ, \\ Sami Uzun, Emel Tatlı, Ahmet Behlül, Leyla Koç, Zeki Aydın, Savaş Öztürk \\ Haseki Training and Research Hospital, Clinic of Nephrology, Istanbul, Turkey \\ *Haseki Training and Research Hospital, Clinic of Internal Diseases, İstanbul, Turkey
}

\begin{abstract}
Dabigatran is used for the prevention of stroke and systemic embolism in patients with nonvalvular atrial fibrillation. It is still unclear whether the use of dabigatran leads to more bleeding compared with warfarin. In this paper, we present a case of intraperitoneal hemorrhage in a 54-years-old male peritoneal dialysis patient using dabigatran for paroxysmal atrial fibrillation because international normalized ratio level could not be kept at target levels during follow-up. The use of dabigatran in atrial fibrillation has become widespread in recent years. Despite the low risk of intracranial hemorrhage, clinicians should be careful in patients with chronic kidney disease because coagulation monitoring is not possible.
\end{abstract}

Keywords: Dabigatran, intraperitoneal hemorrhage, peritoneal dialysis

\begin{abstract}
Dabigatran nonvalvular atriyal fibrilasyon hastalarında inme ve sistemik emboliyi önlenmek için kullanıır. Dabigatranın kullanımının varfarin ile karşılaştııılığında dabigatranın daha fazla kanamaya yol açıp açmayacağı hala belirsizdir. Bu yazıda 54 yaşında, intraperitoneyal hemoraji ile başvuran, takiplerinde uluslararası normalleştirilmiş oranı düzeyleri istenilen düzeyde tutulamadığından paroksismal atriyal fibrilasyon nedeni ile dabigatran kullanan periton diyalizi hastası sunduk. Atriyal fibrilasyonda dabigatran kullanımı yıllar içinde artış göstermiştir. Intrakraniyal kanama riski az olmasına rağmen kronik böbrek hastalarında koagülasyon takibi yapılamadığından dabigatran kullanırken dikkatli olmalıyız.
\end{abstract}

Anahtar Sözcükler: Dabigatran, intraperitoneyal hemoraji, periton diyalizi

\section{Introduction}

Although warfarin remains the most commonly used drug for preventing thromboembolic events in atrial fibrillation, dabigatran, an oral thrombin inhibitor, has been used for this purpose with increasing popularity in recent years. The Food and Drug Administration approved dabigatran for patients with nonvalvular atrial fibrillation for the prevention of stroke and systemic embolism. In addition, when compared with warfarin, dabigatran has a higher risk of gastrointestinal bleeding but a lower rate of intracranial hemorrhage (1). We present here a peritoneal dialysis patient who had intraperitoneal bleeding after use of dabigatran due to nonvalvular atrial fibrillation.

\section{Case}

Our case was a 54-year-old male who had been taken to the peritoneal dialysis program due to diabetic nephropathy for eight years. He had an ischemic stroke in 2008 which was later resolved without sequelae. He was clinically stable and the dialysis adequacy criteria were
Address for Correspondence/Yazışma Adresi: Nilay Şengül Samancı Haseki Training and Research Hospital, Clinic of Internal Diseases, İstanbul, Turkey Phone: +90 5077511588 E-mail: nilaysengulsamanci@gmail.com

Received/Geliş Tarihi: 23 December 2015 Accepted/Kabul Tarihi: 27 December 2015 This study was presented in the $15^{\text {th }}$ Congress of the International Society of Peritoneal Dialysis, September 2014, Madrid, Spain
The Medical Bulletin of Haseki Training and Research Hospital, published by Galenos Publishing. Haseki Tıp Bülteni, Galenos Yayınevi tarafından basılmıştır. 
met. He needed hypertonic peritoneal dialysis solutions intermittently. He had again a cerebrovascular ischemic stroke in November 2012. Echocardiographic examination revealed diastolic dysfunction, dilated left atrium (46 $\mathrm{mm}$ ) and ejection fraction of $50 \%$. Warfarin was given to patient due to suspected paroxysmal atrial fibrillation and two attacks of ischemic stroke. As the international normalized ratio level could not be kept at target levels during follow-up due to noncompliance, dabigatran (150 mg twice a day) was started by a cardiologist in September 2013 without informing the nephrologists.

At the end of the first month of treatment, he was admitted to our unit due to hemorrhagic dialysate for the last three days. Leukocyte count was $0 / \mathrm{mm}^{3}$ and erythrocyte count was $800 / \mathrm{mm}^{3}$ in dialysate. Activated partial thromboplastin time $(116 \mathrm{sec})$ and prothrombin time $(27 \mathrm{sec}$ ) were prolonged. Platelet count was 367.000/ $\mathrm{mm}^{3}$. Hemoglobin level decreased from $10.9 \mathrm{~g} / \mathrm{dL}$ to 9.4 $\mathrm{g} / \mathrm{dL}$. All antiaggregant and anticoagulant medications were stopped and fresh frozen plasma infusion was performed. Hemorrhagic bleeding recovered within two days after the initiation of warfarin treatment.

\section{Discussion}

Dabigatran binds specifically to thrombin with high affinity. Dabigatran etexilate is a pro-drug metabolized in the liver and converted to its active form, dabigatran, after oral administration (2). Although coagulation monitoring is not recommended in routine clinical practice, thrombin time and activated partial thromboplastin time have been used in some studies to monitor the anticoagulant effect of dabigatran. However, ecarin clotting time is the best method for determining the risk of bleeding (3). Some studies have reported that bleeding risk is less with dabigatran compared to warfarin while there are contradicting reports (4). On the other hand, there is no antidote for dabigatran. However, a monoclonal antibody fragment, idarucizumab, versus dabigatran has been developed and indicated for reversing the effects of dabigatran in healthy volunteers. A study evaluating its efficacy for reversal of the anticoagulant effects of dabigatran in patients with serious bleeding is currently underway (5). As $80 \%$ of dabigatran is excreted by the kidneys, the European Cardiology Association does not recommend its use in patients with a glomerular filtration rate of less than $30 \mathrm{~mL} /$ minute (6). Recently, a study has showed that although its use is contraindicated, more dialysis patients are being started on dabigatran (7). There are no studies supporting the benefits outweigh the risks of these drugs in end-stage renal disease patients. Although it is easier to use, physicians should be careful in patients with chronic kidney disease. The use of dabigatran in atrial fibrillation has been increased in recent years in the general population, however, dabigatran should not be used in patients with a glomerular filtration rate below $30 \mathrm{~mL} /$ minute.

\section{Ethics}

Informed Consent: It was taken.

Peer-review: Internal peer-reviewed.

\section{Authorship Contributions}

Surgical and Medical Practices: Nilay Şengül Samancl, Egemen Cebeci, Meltem Gürsu, Serhat Karadağ, Savaş Öztürk, Concept: Egemen Cebeci, Ahmet Behlül, Emel Tatlı. Design: Nilay Şengül Samancı, Egemen Cebeci, Abdullah Şumnu. Data Collection or Processing: Leyla Koç, Zeki Aydın. Analysis or Interpretation: Sami Uzun, Savaş Öztürk, Meltem Gürsu. Literature Search: Nilay Şengül Samancı, Egemen Cebeci. Writing: Nilay Şengül Samancı. Conflict of Interest: No conflict of interest was declared by the authors.

Financial Disclosure: The authors declared that this study received no financial support.

\section{References}

1. Hernandez I, Baik SH, Piñera A, Zhang Y. Risk of bleeding with dabigatran in atrial fibrillation. JAMA Intern Med 2015;175:18-24.

2. Stangier J. Clinical pharmacokinetics and pharmacodynamics of the oral direct thrombin inhibitor dabigatran etexilate. Clin Pharmacokinet 2008;47:285-95.

3. Ezekowitz MD, Reilly PA, Nehmiz G, et al. Dabigatran with or with out concomitant aspirin compared with warfarin alone in patients with nonvalvular atrial fibrillation (PETRO Study). Am J Cardiol 2007; 100:1419-26.

4. Connolly SJ, Ezekowitz MD, Yusuf S, et al. Dabigatran versus warfarin in patients with atrial fibrillation. $N$ Engl J Med;361:1139-51.

5. Glund S, Moschetti $V$, Norris $S$, et al. A randomised study in healthy volunteers to investigate the safety, tolerability and pharmacokinetics of idarucizumab, a specific antidote to dabigatran. Thromb Haemost 2015;113:943-51.

6. Schulman S, Kearon C, Kakkar AK, et al. Extended use of dabigatran, warfarin, or placebo in venous thromboembolism. N Engl J Med 2013;368:709-18.

7. Chan KE, Edelman ER, Wenger JB, Thadhani RI, Maddux FW. Dabigatran and rivaroxaban use in atrial fibrillation patients on hemodialysis. Circulation 2015;131:972-9. 